\title{
Determination of Some Serum Biochemical Parameters of Aksaray Malakli Breed of Turkish Shepherd Dog
}

\author{
Olga Büyükleblebici',a,* \\ ${ }^{I}$ Department of Veterinary, Technical Sciences Vocational School, Mersin University 33100 Mersin, Turkey
}

*Corresponding author

\begin{tabular}{l|l}
\hline A R T I C L E I N F O & A B S T R A C T \\
\hline Research Article & $\begin{array}{l}\text { Aksaray Malakli Shepherd Dog is a native Anatolian race which is raised in Aksaray and it is marked } \\
\text { recently. This study is prepared to reveal significative biochemical properties of Aksaray Malakli } \\
\text { Dog. Blood samples were collected from 20 Malakli dogs which are raised in various animal shelters } \\
\text { in Aksaray region. Biochemical parameters; serum total protein, albumin, globulin, blood urea } \\
\text { nitrogen, creatinine, glucose, total cholesterol, triglyceride, calcium, phosphor, iron, ferritin, and }\end{array}$ \\
$\begin{array}{l}\text { Received : 05/07/2019 } \\
\text { Accepted : 20/08/2019 }\end{array}$ & $\begin{array}{l}6.25 \mathrm{~g} / \mathrm{dL}, 3.62 \mathrm{~g} / \mathrm{dL}, 2.63 \mathrm{~g} / \mathrm{dL}, 16.53 \mathrm{mg} / \mathrm{dL}, 0.88 \mathrm{mg} / \mathrm{dL}, 91.10 \mathrm{~g} / \mathrm{dL}, 186.85 \mathrm{mg} / \mathrm{dL}, 47.65 \mathrm{mg} / \mathrm{dL}, \\
9.53 \mathrm{mg} / \mathrm{dL}, 4.36 \mathrm{mg} / \mathrm{dL}, 112.45 \mu \mathrm{g} / \mathrm{dL}, 0.51 \mathrm{ng} / \mathrm{dL} \text { respectively. and enzyme levels were } 42.50\end{array}$ \\
$\begin{array}{l}\text { Keywords: } \\
\text { Aksaray malakli dog } \\
\text { Biochemical parameters } \\
\text { Paraoxonase } \\
\text { Hepcidine }\end{array}$ & $\begin{array}{l}\text { IU/L, } 31.90 \mathrm{IU} / \mathrm{L}, 43.30 \mathrm{IU} / \mathrm{L}, 166.4 \mathrm{IU} / \mathrm{L}, \text { respectively. Serum Paraoxonase } 1 \text { and hepcidine levels } \\
\text { were measured with ELISA kits manually. Obtained results were } 33.0 \mathrm{ng} / \mathrm{ml} \text { and } 23.55 \mathrm{ng} / \mathrm{ml} \\
\text { respectively. With this study, we determined some serum biochemical parameters of Malakli dog } \\
\text { and we tried to find out the differences between the other Anadolu Coban dogs. Obtained results } \\
\text { may be useful for the next studies about morbidity-health status of these dogs. }\end{array}$
\end{tabular}

Enzyme activity

Türk Tarım - Gıda Bilim ve Teknoloji Dergisi 7(10): 1678-1681, 2019

\section{Aksaray Malaklı Irkı Türk Çoban Köpeğinin Bazı Serum Biyokimyasal Parametrelerinin Belirlenmesi}

\begin{tabular}{|c|c|}
\hline M A K A L E B İ L G İ S İ & Ö Z \\
\hline $\begin{array}{l}\text { Anahtar Kelimeler: } \\
\text { Aksaray malaklisı } \\
\text { Biyokimyasal parametreler } \\
\text { Hepsidin } \\
\text { Paraoksonaz } \\
\text { Enzim aktivitesi }\end{array}$ & $\begin{array}{l}\text { Aksaray Malaklı Çoban Köpeği Aksaray ili ve çevresinde yetiştirilen yakın zamanda coğrafi olarak } \\
\text { işaretlenmiş, yerel Anadolu ırkıdır. Bu çalışmada Aksaray Malaklı Çoban Köpeğinin karakteristik } \\
\text { bazı biyokimyasal özelliklerinin ortaya konması amaçlanmıştır. Aksaray Bölgesindeki çeşitli hayvan } \\
\text { barınaklarındaki toplam } 20 \text { erkek Malaklı köpeğinin serumlarında total protein, albümin, globülin, } \\
\text { kan üre nitrojeni, kreatinin, glikoz, total kolesterol, trigliserit, kalsiyum, fosfor, demir, ferritin } \\
\text { düzeyleri ile ALP, AST, ALT, kreatin kinaz enzim aktivite düzeyleri belirlenmiştir. Elde edilen } \\
\text { sonuçlar biyokimyasal parametreler için sırasıla } 6,25 \mathrm{~g} / \mathrm{dL}, 3,62 \mathrm{~g} / \mathrm{dL}, 2,63 \mathrm{~g} / \mathrm{dL}, 16,53 \mathrm{mg} / \mathrm{dL} \text {, } \\
\text { 0,88mg/dL, } 91,10 \mathrm{~g} / \mathrm{dL}, 186,85 \mathrm{mg} / \mathrm{dL}, 47,65 \mathrm{mg} / \mathrm{dL}, 9,53 \mathrm{mg} / \mathrm{dL}, 4,36 \mathrm{mg} / \mathrm{dL}, 112,45 \mu \mathrm{g} / \mathrm{dL}, 0,51 \\
\text { ng/dL olarak ve enzim düzeyleri de sırasıyla } 42,50 \mathrm{IU} / \mathrm{L}, 31,90 \mathrm{IU} / \mathrm{L}, 43,30 \mathrm{IU} / \mathrm{L}, 166,4 \mathrm{IU} / \mathrm{Lolarak} \\
\text { belirlenmiştir. Hepsidin ve paraoksonaz enzim düzeyleri ise ELISA kitleriyle çalış1lmiştır. Elde } \\
\text { edilen serum Paraoksonaz } 1 \text { ve hepsidin düzeylerinin ortalaması ise } 33,0 \mathrm{ng} / \mathrm{ml} \text { ve } 23,55 \mathrm{ng} / \mathrm{ml} \text { olarak } \\
\text { bulunmuştur. Bu çalışma ile Malaklı köpeklerine ait temel bazı biyokimyasal parametreleri ölçülmüş } \\
\text { ve diğer Anadolu çoban köpekler arasındaki farklılıklar belirlenmeye çalışılmıştır. Elde edilen } \\
\text { sonuçlar bu köpeklerin hastalık-sağlık durumları ile ilgili gelecek çalışmalar için yararlı } \\
\text { olabilecektir. }\end{array}$ \\
\hline
\end{tabular}




\section{Introduction}

Aksaray Malakli Shepherd Dog is a native Anatolian race which is raised in Aksaray. They have droopy labia therefore they are called Malaklı (Aslan et al., 2006; Oğrak et all, 2018) Their colour is mostly grey and have blackyellow head (Figure 1). Recently Aksaray Malakli Shepherd Dog is marked geographically (Atasoy, 2011). There are studies that reveal the differences and similarities of existing dog races in Turkey. Altunok et al. (2005) revealed that Kangal dogs are genetically different from Akbaş dogs. Otherwise as a result of the genetical analyses Mastiff dogs are different from Kangal, Akbaş and Kars shepherd dogs; and may be a different race (Atasoy et al., 2011).

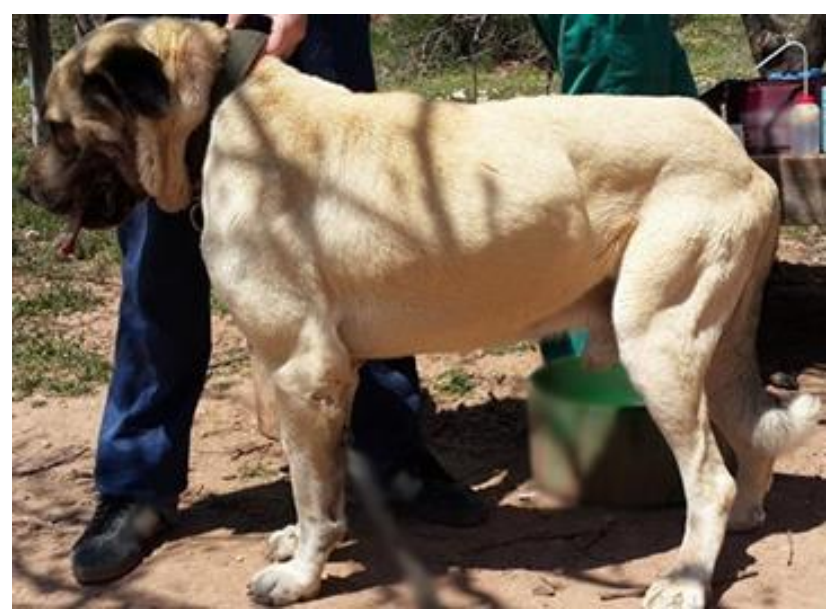

Figure 1 Aksaray Malakli Dog

Blood is an important factor considering health status. Biochemical parameters of blood may give information about physiological and pathological status of animals. Factors like nutrition, stress, heat, season, disease, muscle activity, gestation, lactation, gender, age and race may affect physiologic values of blood parameters (Altunok et al., 2007; Awah et al., 1998; Çınar et al., 2010).

The Paraoxonase 1 (PON 1, aryldialkyl phosphatase, E.C. 3.1.8.1), is an Ca-dependant enzyme that is synthesised in liver. It is related to HDL and has 43-45 kDa molecular weight with glycoprotein structure (Başkol and Köse, 2004). The most important function of PON1 is its anti-atherogenic activity. Serum PON1 exists with HDL in plasma and works to prevent the oxidation of plasma lipoproteins. PON 1 has gained currency about its antioxidant functions in nowadays (Aslan et al., 2007). The studies show that PON1 decreases oxidative stress in tissues and serum (Aviram and Rosenblat 2005).

Hepcidin is a peptide hormone synthesized in liver, found in circulatory and excreted with urine and main organizer of systemic iron balance (Anderson et al., 2007). It inhibits the duodenal iron absorption and secreting of macrophage iron by this way it reduces the iron in organism. Serum iron levels rises while iron loading or inflammation, but levels decreases especially in iron deficiency anaemias. Hepcidin production decreases in anaemia, the inhibitor effect of hepcidin disappears, by this way it ensures using iron for erythropoiesis (Anderson et al., 2007). In this study determining hepcidin levels may give information about anaemia profiles of the animals.
Altunok et al. (2001) analysed the alterations of some main biochemical parameters of 38 healthy Anadolu shepherd dogs due to age and gender in 3 different regions (Konya, Sivas, Gemlik). Kalaycıoğlu et al. (1995) determined the values of total protein, albumin/globulin, AST and sodium, potassium in blood of 10 healthy Kangal dogs. Also Keçeci and Durgun (2001) have specified the reference ranges of some hormones, glucose and total cholesterol levels of Kangal dogs. Çinar et al. also determined the reference ranges of plasma ALT/GGT activities, total cholesterol, total bilirubin, urine, total protein, albumin and globulin levels of Kangal dogs at different age and sex. Shadia (2009) revealed some normal blood parameters of German shepherd dogs who lived at Sudan climatic conditions with different sex and nutrition.

As is seen, the studies about main biochemical parameters of native dog races across the world and Turkey are restricted. And also there hasn't been found a study like this of Aksaray Malakli dogs. With this study, we aimed to determine some serum biochemical parameters of Malakli dog and we tried to find out the differences between the other Anadolu çoban dogs.

\section{Material and Methods}

Blood samples were collected from 20 healthy Malakli dogs (1-3 year-aged; weighted average $80 \mathrm{~kg}$ ) which are raised in various animal shelters in Aksaray region. Biochemical parameters; serum total protein, albumin, globulin, blood urea nitrogen, creatinine, glucose, total cholesterol, triglyceride, calcium, phosphor, iron, ferritin, and ALP, AST, ALT, creatine enzyme activities were measured by autoanalyzer with the reactions of Roche Diagnostic.

Serum paraoxonase 1 and hepcidin levels were measured with ELISA kits manually. The working principle of paraoxonase 1 test relies on double biotin antibody sandwich technology (Canine Paraoxonase-1 Elisa Kit CK-EIA5258 Hangzhau Eastbiopharm Co. Ltd., China). Also hepcidin ELISA Kit has similar working principle (Canine Hepcidin Elisa Kit CK-E11006 Hangzhau Eastbiopharm Co. Ltd., China)

SPSS 17.0 package programme has been used for the statistical assessment of the data (SPSS Inc., Chicago, Illinois, ABD). The arithmetic mean of the data, standard error and standard deviation calculations evaluated with using One Way Annova test; the obtained results were given as $\mathrm{X} \pm \mathrm{Se}$.

\section{Findings and Discussion}

Results were given at Table 1 and Table 2. Kalaycığlu et al. (1995) determined serum total protein and albumin levels as $5.34 \pm 1.38 ; 3.42 \pm 0.64 \mathrm{~g} / \mathrm{dl}$ in Kangal dogs. Altunok et al. (2001) also confirmed albumin levels as $3.47 \pm 0.41 \mathrm{~g} / \mathrm{dl}$ in Anadolu Shephard dogs which were raised at Gemlik. In this study serum total protein, albumin and globulin levels were found as $6.25 \pm 0.09 ; 3.62 \pm 0.06$; $2.63 \pm 0.10 \mathrm{~g} / \mathrm{dl}$ respectively. As total protein and globulin levels were within the reference ranges, albumin levels were higher. The reason for this may be considered as age, maintenance, nutrition, or environmental factors. 
Table 1 Some serum biochemical parameters and enzyme activities. (ALP, AST, ALT, Creatine kinase) of Aksaray Malakli Shepherd Dog

\begin{tabular}{|c|c|c|c|}
\hline Parameters & Reference Ranges* & $\mathrm{M} \pm \mathrm{SH}$ & St. Dev. \\
\hline Total Protein (g/dL) & $5.4-7.5$ & $6.25 \pm 0.09$ & 0.40 \\
\hline Albumin $(\mathrm{g} / \mathrm{dL})$ & $2.3-3.1$ & $3.62 \pm 0.06$ & 0.26 \\
\hline Globulin (g/dL) & $2.7-4.4$ & $2.63 \pm 0.10$ & 0.45 \\
\hline Blood Urea Nitrogen (mg/dL) & $10-28$ & $16.53 \pm 2.07$ & 9.26 \\
\hline Creatinine (mg/dL) & $0.5-1.7$ & $0.88 \pm 0.03$ & 0.15 \\
\hline Glucose $(\mathrm{mg} / \mathrm{dL})$ & $65-118$ & $91.10 \pm 1.97$ & 8.81 \\
\hline Total Cholesterol (mg/dL) & $135-270$ & $186.85 \pm 9.91$ & 44.30 \\
\hline Triglyceride (mg/dL) & 20-112 & $47.65 \pm 2.69$ & 12.02 \\
\hline Calcium (mg/dL) & $9.0-11.3$ & $9.53 \pm 0.10$ & 0.46 \\
\hline Phosphor (mg/dL) & $2.6-6.2$ & $4.36 \pm 0.17$ & 0.79 \\
\hline Iron $(\mu \mathrm{g} / \mathrm{dL})$ & $30-180$ & $112.45 \pm 8.70$ & 38.91 \\
\hline Ferritin $(\mathrm{ng} / \mathrm{mL})$ & $0.29-0.95$ & $0.51 \pm 0.01$ & 0.06 \\
\hline ALP (IU/L) & $1-114$ & $42.50 \pm 5.75$ & 25.74 \\
\hline AST(IU/L) & $23-66$ & $31.90 \pm 3.81$ & 17.02 \\
\hline ALT(IU/L) & $21-102$ & $43.30 \pm 5.24$ & 23.44 \\
\hline CK (IU/L) & $52-368$ & $166.4 \pm 25.6$ & 114.6 \\
\hline
\end{tabular}

*Reference ranges were taken from various sources (Latimer KS 2011, Coles EH, 1986, and Kaneko et al., 2008)

Table 2 Serum paraoxonase 1 activity and hepcidin levels of Malakli dogs

\begin{tabular}{l|rrr}
\hline \multicolumn{1}{c|}{ Variable } & Me \pm Se & S. Dev. & V.K \\
\hline Paraoxonase 1 $(\mathrm{ng} / \mathrm{ml})$ & $33.0 \pm 11.3$ & 50.4 & 152.48 \\
Hepcidin $(\mathrm{ng} / \mathrm{ml})$ & $23.55 \pm 4.34$ & 19.39 & 82.34 \\
\hline
\end{tabular}

In another study, total cholesterol levels were reported as $149.53 \pm 5.39 \mathrm{mg} / \mathrm{dl}$ in male Kangal dogs (Çınar et al., 2010). Here in this study total cholesterol levels were found as $186.85 \pm 9.91 \mathrm{mg} / \mathrm{dl}$ at 1-3 year old male Malakli dogs. This result is a little bit high but it is within the reference ranges.

The mean valuae of urea concentration (is $16.53 \pm 2.07 \times 2.14=35.37 \mathrm{mg} / \mathrm{dl}$ of Malakli dogs in the study and this value is within the ranges that Çinar et al. (2010) reported in Kangal dogs but a little higher than the values that the male dogs have $(22.63 \mathrm{mg} / \mathrm{dl})$. This may be related to distinctness of the race or diet. Serum glucose levels were found as $91.10 \pm 1.97 \mathrm{mg} / \mathrm{dl}$ in Malakli dogs and this is similar with the values that Türkmen et al. (1997) determined in Kangal dogs. Also Shadia (2009) reported that German Shephard dogs have similar serum glucose levels as $114.32 \mathrm{mg} / \mathrm{dl}$ at Sudan.

Aminotransferases like AST (aspartate aminotransferase) and ALT (alanine amino transferase) are used to determine the increment of hepatocellular membrane permeability and GGT (Gama glutamyl transferase) is also used to identify the bile duct diseases commonly. ALT is more specific for liver than AST in dogs and is determined quicker when compare to AST in minor damages. AST is found \%60-80 inside the mitochondria and are secreted after a severe destruction (Turgut, 2000).

In a study Çınar et al. (2010) stated that serum ALT levels were $27.31 \pm 2.80 \mathrm{IU} / \mathrm{L}$ in male Kangal dogs. In this study serum ALT levels were reported as 43.30 $\pm 5.24 \mathrm{IU} / \mathrm{L}$ in Malakli dogs. This value is a little high but it is within the reference ranges. (Kaneko et al., 2008) Türkmen et al. (1997) determined serum AST and ALT levels of Kangal dogs as 35.64 IU/L and 20.02 IU/L in a study which they compared Kangal and German Shephard dogs. Present values in this study were higher than the values that Türkmen et all found but also it is within the ranges that Kaneko et al., (2008) reported.
In iron deficiency anaemia it is believed that oxidative stress rises due to the increase of oxidants and decrease of antioxidant enzyme capacity (Aslan et al., 2006). Aslan et all (2007) determined that paraoxonase 1 and aril esterase activity which have antioxidant properties decreased in iron deficiency anaemia.

Serum iron and ferritin levels were determined as $112.45 \pm 8.70 \mu \mathrm{g} / \mathrm{dL}$ and $0.51 \pm 0.01 \mathrm{ng} / \mathrm{mL}$ respectively (Table 2) in the study. These values are within the ranges and we may say that the dogs that we have taken to this study have no iron deficiency anaemia, and this is also clear with the hepcidin levels of the dogs that we obtained. The obtained values were $23.55 \pm 4.34 \mathrm{ng} / \mathrm{ml}$ and is within the reference ranges (Baştan et al., 2015; Mahadesh et al., 2014; Martinez-Subiela et al., 2014; Rossi et al., 2014; Tvarijonaviciute et al., 2012).

As a result Aksaray Malakli Shephard dog is a native dog that is raised Aksaray region. For this reason, we determined some biochemical parameters in 20 male dogs. Obtained results may give information about their general state of health and may be useful for the next studies about morbidity-health status of these dogs.

\section{Acknowledgement}

This study was supported by the project (ASÜBAP 011) named "Determination of some serum biochemical parameters and bone morphology of Aksaray Malakli Shepherd Dog (Turk Mastiff)".

\section{References}

Altunok V, Maden M, Nizamlioglu M, Togan I. 2001. Some of the frequently used biochemical values of serum and plasma in three different populations of Anatolian shepherd dog. Revue Méd. Vét., 152(3): 261-64. 
Altunok V, Koban E, Chikhi L, Schaffer A, Pedersen NC, Nizamlioglu M, Togan I. 2005. Genetic evidence for the distinctness of Kangal dogs. Bull Vet Inst Pulawy., 49(2): 249-254.

Altunok V, Yazar E, Yuksek N. 2007. Selected Blood Serum Elements in Van (Turkey) Cats. Acta. Vet. Brno, 76:(1) 171177.

Anderson GJ, Darshan D, Wilkins SJ, Frazer DM. 2007. Regulation of systemic iron homeostasis: how the body responds to changes in iron demand. Biometals, 20(3): 66574.

Aslan M, Horoz M, Koçyğit A. 2006. Lymphocyte DNA damage and oxidative stress in patients with iron deficiency anemia. Mutation Research, 601(2): 144-149.

Aslan M, Kösecik M, Horoz M. 2007. Assessment of paraoxonase and arylesterase activities in patients with iron deficiency anemia. Atherosclerosis, 191(1): 397-402.

Atasoy F. 2011. Türk mastifi köpeklerin morfolojik ve Genetik Özelliklerinin belirlenmesi ve bu köpeğin tanıtılması. 1. Bask1, Ankara: Medisan Matbaacılık.

Atasoy F, Mustafa U, Özarslan B. 2011. Halk elinde yetiştirilen Akbaş köpeklerinde canlı ağırlık ve vücut ölçüleri. Ankara Üniv. Vet. Fak. Derg., 58: 213-215.

Aviram M, Rosenblat M. 2005. Paraoxonases and cardiovascular diseases: Pharmacological and nutritional influences. Curr. Opin. Lipidol., 16: 393-399.

Awah JN, Nottidge HO. 1998. Serum biochemical parameters in clinically healthy dogs in Ibadan. Trop. Vet., 16(2): 123-129.

Başkol G. ve Köse K. 2004. Paraoxonase: biochemical features, functions and clinical imporatance. Erciyes Med. J. 26(2): 7580.

Baştan A, Kanca H, Baştan İ, Salar S, Karakaş K, Alkan H, Sel T. 2015. Serum ceruloplasmin and paraoxonase-1 levels in ovariectomized and ovariohysterectomized dogs. Ankara Üniv. Vet. Fak. Derg., 62(3): 211-215.

Coles EH. 1986. Veterinary Clinical Pathology. 4th edition. W.B. Saunders Co. Philadelphia.

Çınar M, Erat S, Arıkan Ş, Mamak N, Oğrak YZ, Güzel M. 2010. Kangal köpeklerinde bazı biyokimyasal parametreler üzerine yaş ve cinsiyetin etkisi. J. Fac. Vet. Med. Univ. Erciyes, 7(2): 109-16.
Kalaycıoğlu L, Nizamlıŏlu M, Altunok V. 1995. Sağlıklı kangal köpeklerinde kanda bazı biyokimyasal parametreler. Vet. Bil. Dergisi, 11(1): 47- 49 .

Kaneko JJ, Harvey JW, Bruss ML. 2008. Clinical Biochemistry of Domestic Animals, 6th Ed., Academic Press,

Keçeci T, Durgun Z. 2001. Pointer, Alman Çoban Köpeği ve Kangal ırkı kopeklerde kan serumu tiroit hormonları, glikoz ve total kolesterol düzeyleri. Vet. Bil. Derg., 17(4): 5-8.

Latimer KS. 2011. Duncan and Prasse's Veterinary Laboratory Medicine: Clinical Pathology, 5th Edition, Wiley-Blackwell. ISBN: 978-0-813-82014-9.

Mahadesh AJ, Krueger M, Krueger M. 2014. Decreased level of serum paraooxonase activity in dogs with dilated cardiomyopathy. Journal of Vet. Med. and An. Health. Vol. 6(9): 245-250.

Martinez-Subiela S, Ceron JJ, Strauss AD, Garcia-Martineza JD, Teclesa F, Tvarijonaviciute A, Caldin M, Baneth G. 2014. Serum ferritin and paraoxonase-1 in canine leishmaniosis. Comp. Im. Micr. and Infect. Dis,. 37(1): 23-29.

Oğrak YZ, Öztük N, Akın D, Özcan M. 2018. Comparision of various body measurement of Aksaray Malaklı and Kangal dogs. JIVS. Vol 2(3): 86-91.

Rossi G, Ibba F, Meazzi S, Giordano A, Paltrinieri S. 2014. Paraoxonase activity as a tool for clinical monitoring of dogs treated for canine leishmaniasis. The Vet. Journal, 199(1): $143-149$.

Shadia AO. 2009. Normal values of some serochemical parameters in male and female German shepherd dogs in Sudan. Assiut. Vet. Med. J., 55(120): 110-115.

Turgut K, 2000: Veteriner Klinik Laboratuvar Teşhis. 179-201, 2. baskı. Bahçıvanlar Basımevi, Konya.

Türkmen G, Özcan M, Mengi A. 1997. Kangal ve Alman çoban köpeği ırklarının bazı biyokimyasal kan parametrelerinin karşılaştırılması. İstanbul Üniv, Vet. Fak. Derg., 23 (2): 301310 .

Tvarijonaviciute A, Kocaturk M, Cansev M, Tecles F, Ceron JJ, Yilmaz Z. 2012. Serum butyrylcholinesterase and paraoxonase 1 in a canine model of endotoxemia: Effects of choline administration. Res. in Vet. Sci., 93: 668-674. 